$\frac{\text { DE }}{\mathrm{G}} \stackrel{\substack{\text { DE GRUYTER } \\ \mathrm{GPEN}}}{\frac{\text { ECONOMIC THEMES (2014) } 52(3): 281-296}{\text { DOI 10.1515/ethemes-2014-0018 }}}$

\title{
COOPERATION BETWEEN THE REPUBLIC OF SERBIA AND EUROPEAN UNION IN THE PERIOD OF OPENING NEGOTIATIONS ON ACCESSION
}

\author{
Maja Gavrilović \\ $\triangle$ majchegavranche@gmail.com \\ Dragana Radenković Jocić \\ University of Niš, Faculty of Economics, Serbia \\ $\bowtie$ draganarj61@gmail.com
}

UDC
339.92
$\left(497.11: 4^{-}\right.$
672EU)
Review paper

Received:

02.06.2014

Accepted:

10.10.2014

\begin{abstract}
The negotiation act between Serbia and the European Union began on the basis of Article 49 of the EU Contract. The act and development of negotiations will be led by Serbia's progress in the accession preparation, especially within the frame of economic and social convergence. The progress will be measured especially in meeting the Copenhagen criteria, as well as the requirements defined by the Stabilization and Association Agreement. Also, the accession implies accepting the institutional framework of the Union, known as acquis. Acquis special importance for Serbia as a candidate country have regarding economic issues and its jurisdiction.In this sense, it is of great importance to have an overview of facts presented in the paper, which relate to certain economic categories, primarily the movement of Gross domestic product and rate of (un)employment, as well as the steps that Serbia took on their way to the Union.
\end{abstract}

Keywords: accession, GDP, employment, harmonization, competitiveness

\section{Introduction}

The region of Southeastern Europe, including the Balkans, has started the process of accessing the European Union notably later than all the other parts of Europe which the members belong to. This situation is not so surprising if we take into consideration all the events, on one, and development degree of all the

The paper is the result of research realized within projects 47005 and 179066 financed by the Ministry of Education, Science and Technological Development of the Republic of Serbia. 
social relations in these territories, on the other side. There was a certain shape of multilateral cooperation in the Balkans, but it was only temporary and there has always been a certain amount of insecurity, or to be more precise, imprecision. Until 1970's, all attempts at a wider and deeper cooperation between the region's countries were primarily oriented on the question of security and establishing boundaries, and to a lesser extent, on the economic safety and cooperation. The Balkans countries have succeeded in realizing short-term regional organizations no more than two times: the first attempt resulted in the Agreement of the Balkans entente of 1934, which lasted for six years, and the other Balkans alliance of 1953, which functioned for two years only. (Marković, 2009, p. 201).

Initiatives of new cooperation occurred at the crossover between the 1980's and 1990's. The reason of creating new initiatives occurred as a result between two processes. The first one was the separation of the Eastern Bloc, where the cooperation was heading towards tighter connection with the European Union. The second wave, or process, was the process of dissolution of the SFRJ. Following the armed conflicts, the ideas that came were aimed at stabilizing the region and establishing multilateral cooperation. These were the Conference on Stability, Safety and Cooperation, later to be named South-East European Cooperation Process (SEECP) of 1996, the Royaumont Process of 1996, the Southeast European Cooperative Initiative (SECI) of 1997, the Stability Pact for Southeastern Europe (SPSE) of 1999. Serbia, in comparison to other countries of the Western Balkans, was the last to start negotiations on accessing EU. The process of negotiation and accessing the Union at different times is only partly due to the armed conflicts, and mostly due to the unequal economic development of the countries, as well as the underdevelopment of the countries and incompatibility of their economies. The regional cooperation development was supported by both USA and the EU, and this support regarded both the improvement of economic position and strengthening of international position and safety, and especially approaching the European and Euro-Atlantic integrations. At the Ministerial Conference which was held in Thessaloniki in 1997, the following motion was ratified: "The European orientation of the region's countries is an integral part of the political, economic and social development. Their intention is to actively contribute to the European integration, motivated and with such principles which helped establish and develop what is today known as the European Union". ${ }^{1}$

All the afore mentioned initiatives had the goal to improve the multilateral cooperation, which presents a basis for the economic development, political and economic stabilization and establishment for a good regional cooperation. It can be said that the cooperation in the Southeastern Europe is being realized through four frameworks (Marković, 2009, p. 203, 204 i 205). 
First of the four frameworks is the International Framework, which is concerned with support of the whole international unity, which conditions, directs, encourages and to a great extent finances regional cooperation. Financing is supported by the International Monetary Fund, World Bank and their agencies, and the World Trade Organization.

The second framework is European, which is involved in the previously mentioned framework, with the tendency of becoming dominant. According to the majority of authors, the region-oriented politics of the EU was conducted on three levels: the first is establishing the Stability Pact for South Eastern Europe, which has the widest range and the biggest international support, the second is the Stabilization and Association Process, and the third level is the CARDS program since it is realized through the national CARDS programs. The European Commission supplemented them with regional CARDS, so as to achieve regional cooperation predicted by the Stabilization and Association Agreement. $10 \%$ of all the available funds were used for this.

The Regional Framework presents a sum total of all the activities of this region's countries, aligned with the international and European Framework of regional cooperation and motivated, primarily, by the interests of their own development. Insufficient efficiency of the international initiatives in the region can be attributed to the very countries of the region, as there is not enough initiative to use the available and seek new opportunities. The last few years have shown an increase of the countries' activities, which indicates a sound awareness about this being the only way of joining the Union.

The fourth framework can surely be the Sub-Regional Framework, according to which the countries are, by the rule, oriented on solving a regional problem, and are based on the interest logic, and the most often regions of cooperation are the infrastructure, transport, ecology and the overseas cooperation, culture and sports.

In order for the economic cooperation to be realized and the accession criteria fulfilled, it is necessary to first accomplish stability in the region. This task is especially important for the Western Balkans. Without establishing peace and stability it is completely irrational to expect for the economic cooperation to be established.

\section{Serbia's 'Normative Path' to the European Union}

It is well known that the EU commission is constantly setting more demands for the Western Balkans regarding the administrative sector, but also regarding the creation of public politics implementation. All of these activities are realized in the contest of accepting and implementation of the legal heritage of the EU. New conditions for today's candidate countries are a result of certain difficulties 
which occurred during the 'numerous' accessions in 2004. In order to overcome all the potential obstacles, the EU commission, alongside OECD made the Support for Improvement in Governance and Management known as the Sigma Program. The basic aim of the Program was to create legal framework for estimating progress of the candidate countries, that is, the baselines for establishing the EU accession criteria, for so called horizontal reforms. Namely, the baselines were related to five areas that were defined as crucial for horizontal aspects of ruling.

According to Article 4(3) of the European Union Contract, every country that aims for full membership must take adequate measures inter alia, whether general or individual, in order to make sure they fulfill the obligations from the Establishment Agreement and other acts of the Union's institutions. (Schimmenlfenning, Sedelmeier, 2004, p.506) Should we compare the enactments of the first Establishment Agreement to the commitment in force, we will see the growing level of obligations and the member states as well as the states preparing for realization of their wishes for the EU membership. According to Article 13 Treaty of European Union, paragraph 1, as a part of the Lisbon Contract, it is an obligation of the state members of the Union to promote the values of the EU, progress in achieving goals, interests, as well as to provide consistency, efficiency and the continuity of politics and activities. When it comes to candidate countries it is clear that they need to have strong administrative 'capacities', in order to be able to end all the negotiation chapters, on one side, but also, to be ready for the process of adopting and applying legal acts on the level of Union (Featherstone, Radelli, 2003, p.67).

Serbia has made big and very important steps on this 'European' road. ${ }^{1}$ There is no doubt that certain alterations in the country's legal framework should have taken place at the very beginning. Important alterations of the most important act, that is the state constitution, are only just awaiting Serbia. However, everything that has been done up to this moment has made way for important progress in the status of Serbia from one of the candidates for the EU membership to opening negotiation chapters for is accession to this subject. However, it is a fact that there is one plan document missing, which would include all the priorities, including the system of planning public politics. ${ }^{2}$ Serbia, as one of the candidate countries, does not follow the same path the other countries of same statute had. So, the steps that candidate countries take in the process of negotiation can differ for each country, but it is doubtless that mutual elements can be recognized, especially in the procedural activities (Communication from the Commission to the European Parliament and the Council, COM 2013, 700 final). In general, Serbia has experiences of numerous state members to compare and draw conclusions which can serve as great introduction to the membership. Analyses show that, having the current status and problems of Serbia in mind, one should consider the example of the United 
Kingdom (at the time of UK's accession), Latvia and Poland. Mainly, it is necessary to have the analysis of the problems and clearly defined goals as starting points of the long European road. In this manner, all of the participants will find it easier to later implement all the measures taken.

\section{Serbia as a part of EU's internal market}

The economic integration with the EU, yes or no, and how should Serbia answer this question? The numbers in this case are the most accurate indicators. Namely, the Union is Serbia's leading business partner $-58,1 \%$ of the whole export and 58,2\% of import in Serbia in 2012 was directed towards the Union. Compared to the previous year, there is an insignificant defeat on both sides. Serbia's export into EU is in faster growth than its import. The state members of CEFTA record $32.4 \%$ of whole export and $10.4 \%$ of its import in 2012 in relations with EU. This shows that the trade integration with EU still remains at a significant level.

Taking into account a certain parametric (in economic sense), it can be noted that positive steps were taken in Serbia. What is Serbia has done so far and what lies ahead in order to meet all the requirements in order to establish a market system that can successfully work with a market system that exists in the European Union It is certainly necessary to conduct numerous reforms, mainly legislative, and then restructuring of the economy.

One of the more important factors that can prove there is a growth in the economy is the movement of the gross domestic product. Namely, the period of 2000-2008 showed growth of GDP in Serbia.

Table1 Movement of the Growing Rate of GDP in Serbia in the period of 2000-2008

\begin{tabular}{|l|l|l|l|l|l|l|l|l|l|}
\hline \hline & $\mathbf{2 0 0 0}$ & $\mathbf{2 0 0 1}$ & $\mathbf{2 0 0 2}$ & $\mathbf{2 0 0 3}$ & $\mathbf{2 0 0 4}$ & $\mathbf{2 0 0 5}$ & $\mathbf{2 0 0 6}$ & $\mathbf{2 0 0 7}$ & $\mathbf{2 0 0 8}$ \\
\hline BDP & $5,3 \%$ & $5,6 \%$ & $3,9 \%$ & $2,4 \%$ & $8,3 \%$ & $5,6 \%$ & $5,2 \%$ & $5,5 \%$ & $5,4 \%$ \\
\hline
\end{tabular}

Source: www.mrrls.gov.rs

By taking a look at the data from chart 1 , one can conclude that the growth of gross domestic product in the period of 2005-2008 was relatively stable and it amounted about 5\%. As 2009 was the year of worldwide crisis, this also reflected on Serbia. 2009 saw the decrease of gross domestic product by $3,1 \%$. No sooner than 2010, the economy started to recover, and made progress of only $1 \%$ of the GDP. However, economic recovery was stimulated by the growth of export into the EU, which unfortunately stopped mid 2011 due to the negative effects of the global economic crisis, especially due to the decline of 
economic growth and financial problems in the euro zone. ${ }^{1}$ The result of all of this is that, even in the deteriorated conditions, 2011 brought a realistic growth of GDP by $1.6 \%$ which was a consequence of the increasing industrial and agricultural development, construction, traffic and telecommunications. The largest positive contribution to the growth of GDP comes from the sector of informing and communications at $0,9 \%$, the sector of industry at $0,6 \%$, while the largest negative effect was the consequence of the decrease in trade of GDP at $-1,7 \%$. The reason for this was the fall of final consumption. Besides this, there has been a fall of investment in fixed assets in the value of $-3,4 \%$. However, there have been some unfavorable movements of economic activities of the countries that are connected with Serbia through foreign trade (mostly the countries of the European Union), so all of this has affected the decrease of demand for Serbian products, as well as the decrease of economic growth. For sake of clearer view, and comparison to other countries in the Region, the movement of gross domestic product will be presented both through chart and graph.

Table 2 Movement of the rate of GDP in Serbia and region in the period of 2001-2012 2

\begin{tabular}{||c|c|c|c|c|c||}
\hline & $2001-2008$ & 2009 & 2010 & 2011 & 2012 \\
\hline EU 27 & 2,0 & $-4,3$ & 2,1 & 1,6 & $-0,3$ \\
\hline Bulgaria & 5,8 & $-5,5$ & 0,4 & 1,8 & 0,8 \\
\hline Hungary & 3,2 & $-6,8$ & 1,3 & 1,6 & $-1,7$ \\
\hline Romania & 6,3 & $-6,6$ & $-1,1$ & 2,2 & 0,3 \\
\hline Croatia & 4,3 & $-6,9$ & $-2,3$ & 0,0 & $-2,0$ \\
\hline Serbia & 4,9 & $-3,5$ & 1,0 & 1,6 & $-1,7$ \\
\hline B and H & 4,9 & $-2,9$ & 0,7 & 1,3 & \\
\hline Montenegro & 5,0 & $-5,7$ & 2,5 & 2,8 & \\
\hline Macedonia & 3,0 & $-0,9$ & 2,9 & 2,8 & 0,0 \\
\hline
\end{tabular}

Source: www.mrrls.gov.rs

By looking at this data, we can conclude that Serbia has followed movements in the region and that even some negative results were mostly the consequence of economic events and crises which were out of the reach of the economic powers in the country.

\footnotetext{
${ }^{1}$ Portal of the National Assembly of the Republic of Serbia, http://www.parlament.gov.rs/, The fiscal strategy for 2013 with projections for 2014 and 2015, p.7. Document taken 28.09.2013 at 15:36.

2 Portal of the Ministry of Regional Development and Local Government, www.mrrls.gov.rs, Report on development of Serbia for 2012, p. 21. Document taken 28.09.2013 at 16:13.
} 
Graph 1 Movement of the \% of GDP in Serbia and region in the period of 2001-2012 ${ }^{3}$

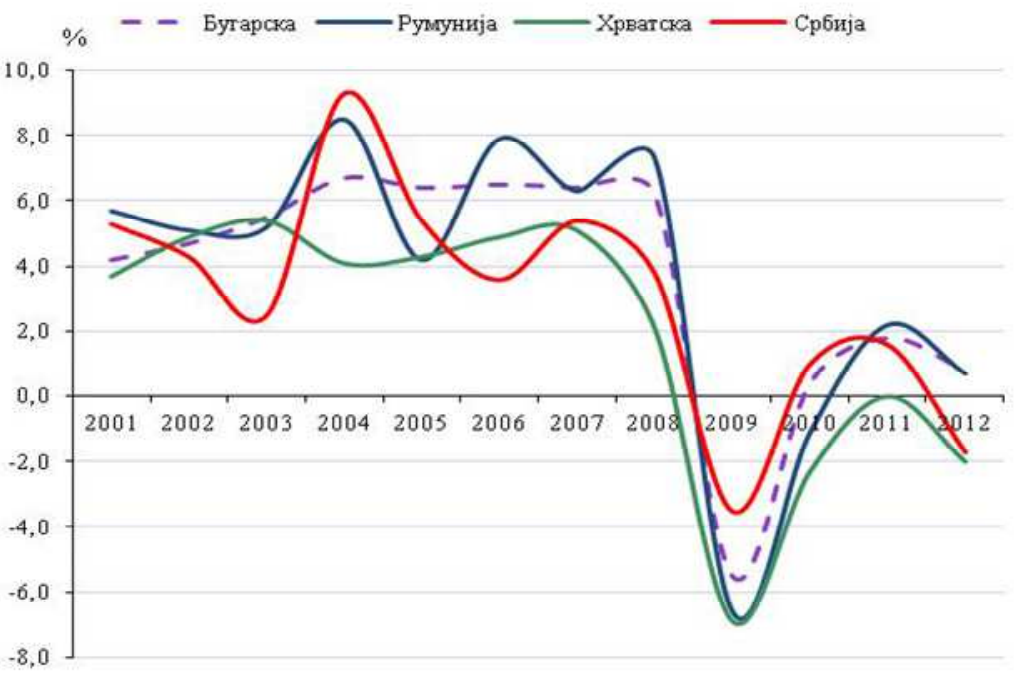

Source: Eurostat, RZS

Another important indicator of a country's economic growth is inflation. Observing the period from 2001-2012, it can be stated that macroeconomic stability was established at this time. The relative stability in price was gained by the conditions of established liberalization of the market, refrorms of fiscal system, along with phased elimination of the most important pricing disparity. Although inflation has notably decreased over time, its average annual level of $12,5 \%$ has pointed to the existence of the internal macroeconomic imbalance. Cyclic fluctuations in the movement are characteristic for the transitional period. Despite the positive trend (from 40,7\% in 2001 to $12,2 \%$ in 2012) the overall inflation is still very high. In the period of 2001-2008 the inflation was measured by retail price method, and from 2009 the official measure of inflation in Serbia has been the growth of consumer prices. By the end of 2012, inflation has reached the YOY level of $12,2 \%$, and the average annual growth of consumer prices was $7,8 \%$ and it was above the projected values. The target rate of inflation was $4 \%+/-1,5 \%$ However, the growth of consumer prices was largely due to the growth of food price which was induced by the unfavorable agricultural season and the growth of primary agricultural products' global prices. Compared to its neighboring countries, Serbia has the highest average annual rate of inflation, which was $11,2 \%$ in 2011. The higher inflation in Serbia compared to the inflation in neighboring countries led to the increase in prices of domestic import. This increase in import has caused increase in search

3 Portal of the Republic Institute for Statistics of the Republic of Serbia, www.statserb.sr.gov.yu, chart taken 28.09.2013. at 16:25. 
of the foreign currency and has led the sale of domestic currency to depreciation of national currency. Namely, if we observe the inflation in 2009 and 2010, it has decreased in comparison to the earlier period, which is the result of the Government's measures, depicted in the freeze of pensions and salaries in the public sector in this time interval. The result of it all was that in December 2011, inflation was by 7\% higher than targeted, and in 2012 it was targeted to $4 \%+/-1,5 \%$. However, the inflation was significantly higher, which is not to be found unusual, considering the conditions in agriculture, but also the inclusion of VAT of $20 \%$, even though until then it was $18 \%$.

Table 3 Macroeconomic movements in Serbia in the period of 2001-2012 4

\begin{tabular}{|c|c|c|c|c|c|c||}
\hline & 2001 & 2008 & 2009 & 2010 & 2011 & 2012 \\
\hline GDP in billions of Euros & 12,8 & 32,7 & 28,9 & 28,0 & 31,5 & 29,9 \\
\hline $\begin{array}{c}\text { GDP, realistic to the growth } \\
\text { of \% }\end{array}$ & 5,3 & 3,8 & $-3,5$ & 1,0 & 1,6 & $-1,7$ \\
\hline Inflation, the end of period & 40,7 & 6,8 & 6,6 & 10,3 & 7,0 & 12,2 \\
\hline Rate in RSD/EUR (avg.) & 59,78 & 81,44 & 93,95 & 103,04 & 101,95 & 113,3 \\
\hline $\begin{array}{c}\text { Deficit of running budget \% } \\
\text { GDP }\end{array}$ & 2,2 & $-21,6$ & $-6,6$ & $-6,7$ & $-9,1$ & $-10,5$ \\
\hline $\begin{array}{c}\text { Foreign direct investments } \\
\% \text { GDP }\end{array}$ & 1,4 & 5,6 & 4,8 & 3,1 & 6,1 & 0,8 \\
\hline $\begin{array}{c}\text { Reserves of NBS in billions } \\
\text { of EUR }\end{array}$ & 1,33 & 8,19 & 10,6 & 10,0 & 12,1 & 10,9 \\
\hline Fiscal deficit \% GDP & $-0,5$ & $-2,6$ & $-4,5$ & $-4,7$ & $-4,9$ & $-6,4$ \\
\hline Public debt \%GDP & 105,2 & 29,2 & 34,7 & 44,5 & 48,2 & 59,3 \\
\hline External debt \%GDP & 85,5 & 64,5 & 77,7 & 84,9 & 76,7 & 85,9 \\
\hline $\begin{array}{c}\text { Private external debt \% } \\
\text { BDP }\end{array}$ & 5,5 & 44,6 & 50,8 & 52,5 & 42,4 & 45,2 \\
\hline \hline
\end{tabular}

Source: www.mrrls.gov.rs,

The movements of gross domestic product and inflation, but also of other indicators shown in the chart, which are of great importance for one country's economy, reflect on the life standard of the society. In this way, life standard is one of the important indicators in analyzing the economic indicators which are of importance for joining the European Union. The growth of life standard in the period of 2001-2008 was a result of the dynamic growth of salaries and pensions. The underlying problem is that the advantages of the economic growth were transferred onto the society through the growth of salaries, and not through the growth of employment. The average salary reached the level of 400 Euros, which makes one third of the European average. However, the coming of

${ }^{4}$ Portal of the Ministry of Regional Development and Local Government, www.mrrls.gov.rs, Report on development of Serbia for 2012, p. 25. Document taken 28.09.2013. at 16:13. 
global economic crisis was followed by the fall of economic activity and decrease of growth in salaries, as well as growth in unemployment. The logical consequence of the deteriorated macroeconomic situation is the deteriorated life standard. The second wave of the economic crisis in 2012 brought even more negative movements in the field of trade, average salary fell to as much as 366 Euros ${ }^{5}$. If we should take a look at the surroundings, Serbia has higher salaries in comparison to Bulgaria, Macedonia and Romania, but lower in comparison to Croatia, Hungary and Bosnia and Herzegovina.

Negative trends of employment decrease and unemployment increase before the transitional period continued, even in the years of biggest economy growth. As previously mentioned, there was an increase in pensions and salaries, but the number of employees was still decreasing. With the decrease of employees, structural problems of economy and society came to surface. The reason for this was the duality of the labor market in Serbia, where a number of employees had a high certainty of employment, whereas the other part of the employees works on the so called margins and has very low certainty of employment. Namely, the private sector has adjusted and continues to adjust to the newly created economic conditions. However, the public sector was not properly adjusted to the given situation. The very high level of unemployment is the consequence of the transitional restructuring through layoff in privatized companies, and this problem is becoming more and more present because of the continuing ownership transformation and company restructuring. Positive signals were marked in October 2012, when the level of unemployment decreased by $1,2 \%$, which makes 8270 people. $^{6}$ The labor market in Serbia is characterized by the inadequacy between the supply and demand for workforce, and this inadequacy is constantly increasing due to the discrepancy in the qualifying age and professional structure.

The rate of unemployment in Serbia is $24,6 \%$, and the average rate in the European Union is $10,3 \%$. It is also important to note that in Serbia there is a high rate of unemployment of about $51 \%$ for people yonger that 25 , while in the Union it is $22,6 \%$. In the process of restructuring from 2007 to 2012, 92000 people lost their jobs, 85000 of which were in the real sector and 7000 in the public sector. A part of this was absorbed by the entrepreneurial sector in during 2008. However, as soon as in 2009 , the entrepreneurial sector reduced the number of employees by 106,000 , which is $21,5 \%$. What can be concluded from chart no. 4 is that the rate of unemployment has increased, and the rate of employment has decreased. The period that was described in the chart was from 2008 to April 2013. Hereby, the data relate to the percentage of working-age population older than the age of 15 .

\footnotetext{
${ }^{5}$ National Statistics Office, www.statserb.sr.gov.yu. Website visited: 15.11.2013 at 18:16.

${ }^{6}$ Portal of the Ministry of Regional Development and Local Government, www.mrrls.gov.rs, Report on development of Serbia for 2012, p. 12. Document taken 28.09.2013.u 16:13.
} 
Table 4 Movement of rate of employment/unemployment in Serbia in the period of $2008-2013^{7}$

\begin{tabular}{|c|c|c|c|c|c|c||}
\hline & 2008 & 2009 & 2010 & 2011 & $\begin{array}{c}2012 / \\
\text { oct }\end{array}$ & $\begin{array}{c}2013 / \\
\text { apr }\end{array}$ \\
\hline \multicolumn{7}{|c||}{ Rates of activity, employment, inactivity, unemployment } \\
\hline REPUBLIC OF SERBIA \\
\hline Rate of unemployment & 14.4 & 16.9 & 20.0 & 23.6 & 23.1 & 25.0 \\
\hline Rate of employment & 53.7 & 50.4 & 47.2 & 45.4 & 46.4 & 45.8 \\
\hline
\end{tabular}

Source: www.mrrls.gov.rs

One of the more important economic indicators is the currency of dinar. The National Bank of Serbia follows the policy of the floating exchange rate. The economic crisis of 2008 and its second wave in 2011 resulted in the destabilization of the exchange market and devaluation of national currencies worldwide, not just in Serbia. In 2008 dinar got devalued by $4.9 \%$ and in 2009 by $2.3 \%$, as well as $3.1 \%$ in 2010 . In 2011 dinar started to float differently as it began to revalue. Dinar revalued by $4.4 \%$ which was a clear indication that the financial resistance of Serbia to outside shocks became stronger than it had been a few years back. The following year, dinar devalued in relation to that of euro by $8 \%$ and by $6.2 \%$ in relation to the American dollar.

One of many such indicators are foreign direct investments which, from 2001 to 2012 amounted to 15.1 billion euros net worth in Serbia, as they peaked in 2006 by reaching 3.3 billion dollars worth of investment. The major part of foreign direct investments covered the purchasing of parts of domestic government-owned and public corporations, as well as banks, through privatization by tender offering and auctions. In 2012, these investments in Serbia amounted to only 231.9 million euros net worth which was a significant decrease in relation to the previous years. In 2011, 1.8 billion euros were invested, which were at that point the highest amount of foreign direct investments in relation to the whole region.

There were a number of public financial reforms in the past 12 years that resulted in the modernization of the fiscal system. The taxation system became competitive in the region and was highly harmonized with the standards of the European Union. From 2005 to 2012, the public expenditure of Serbia took large part with $45.8 \%$ of the overall gross domestic product. It was during the crisis that the poor size and structure of the public spending came to prominence in Serbia. In 2012, the public expenditure took part in gross domestic product with $47,9 \%$. The fiscal position of Serbia worsened after a surplus was accomplished in 2005 and in effect the public debt resulted in a serious deficit

\footnotetext{
${ }^{7}$ National Statistics Office, www.statserb.sr.gov.yu. Website visited: 15.11.2013. at 18:16.
} 
which naturally got financed via loans which unavoidably lead to the public debt being a part of the overall gross domestic product. Having in mind that the one of the prerequisites in order to join the European Union is cooperation with the International Monetary Fund, the fiscal deficit was in 2009 and 2010 acceptable, in regard with what was agreed on with the International Monetary Fund (4.5\% and $4.7 \%$ respectively). The numbers were similar in 2011 (4.9\%), whilst in 2012 the deficit noticeably increased to 6.4\%. Improving the legal framework and creating modern institutions will bring about a more effective functioning of the complete system of public finances. This claim is supported by the fact that the Government of Serbia adopted in 2012 the fiscal strategy for 2013 with the projections for 2014 and 2015.

Namely, by looking at the following graph we may notice the flow of the aforementioned parameters which indicate the state of the economy.

Graph 2 The flow of the basic economic indicators for Serbia from 2001 to $2012^{8}$

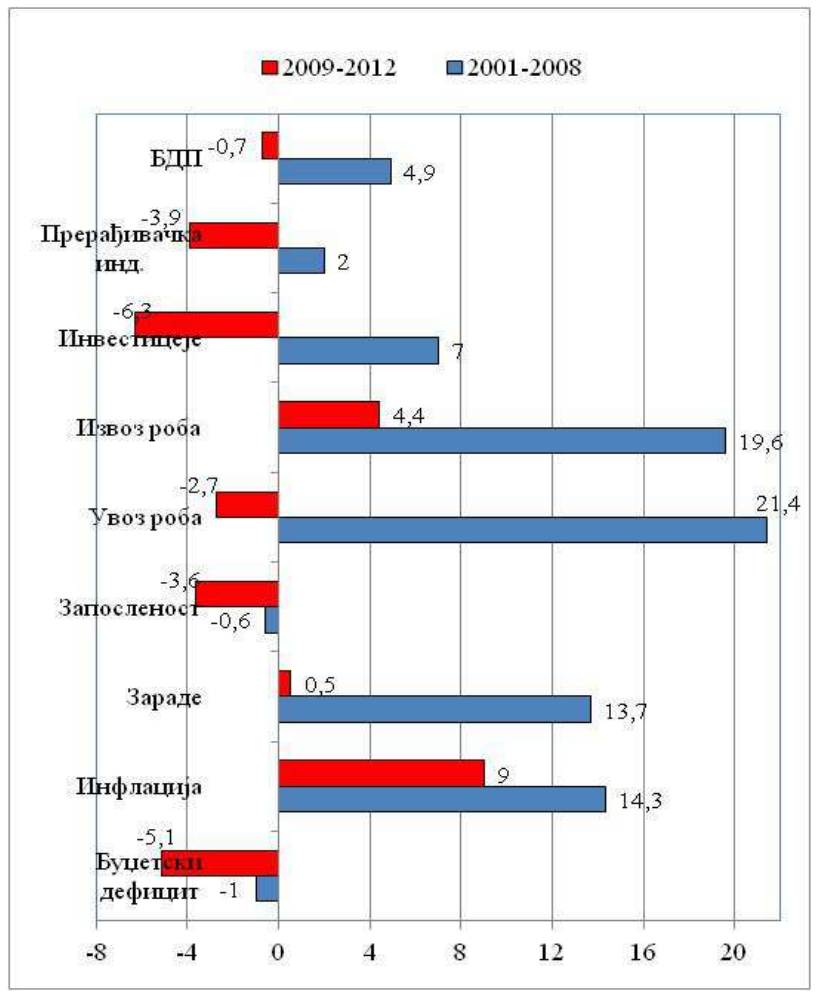

\footnotetext{
${ }^{8}$ Portal of the Ministry of Regional Development and Local Government, www.mrrls.gov.rs, Report on development of Serbia for 2012, p. 8. Document taken 28.09.2013 at 16:13
} 
All these indicators show with unamity that Serbia was on a great economic rise up until 2008. Afterwards, due to the worldwide crisis a number of shocks occurred which undermined the freshly started economic progress in Serbia.

\section{The process of integration of Serbia and European Union}

In order to establish cooperation with the European Union on all fields and especially the economic one, Serbia has to be a part of the process of integration. There are several reasons that lead to the conclusion that Serbia should become a member of the European Union and one of those reasons is by all means its central position in the Balkans. Serbia has clear intentions in forming bilateral and multilateral partnerships with the countries from the region and the members of the European Union as well. Namely, regional partnership and cooperation are implied because they symbolize a requirement for the upkeep of peace and stability in the region both politically and economically.

Bilateral partnership of Serbia with the European Union is institutionally reflected in signing different types of agreements and treaties in the field of economy, infrastructure, culture, science, education, sport etc. When it comes to functional cooperation, it can occur on both horizontal and sector levels (Marković, 2009, p.207). Sectoral cooperation implies partnership in the field of foreign commerce, forming a mutual investment space, a mutual electric power market, partnerships in the field of infrastructure and joint war against organized crime. This type of partnership implies cooperation between sectors which in turn implies cooperation between two or more countries. Horizontal cooperation implies establishing direct connection and partnerships between two concrete parties in order to accomplish a certain goal or reach certain interests. This type of cooperation does not require the involvement of the Government. For example, horizontal cooperation is represented by a connection between two places in two different countries, by a formed network of commerce boards, and many times by partnerships between educational and cultural institutions which are solely voluntary.

Establishing multilateral partnerships with the countries in the region is completed through three steps of integration processes: euroatlantic (the European Council, the European Union and NATO), those directed towards the Balkans itself (Stability Pact for South Eastern Europe, South-East European Cooperation Process) and those directed towards the neighboring regions (Central European Initiative, Adriatic Ionian Initiative, the Danube Cooperation Process, Organization of the Black Sea Economic Cooperation) (Marković, 009, p. 207). The first round implies the process of harmonization and cooperation between the countries which in turn implies for the countries of the Western 
Balkans the process of stabilization and joining which then opens up the space for entering the European Union.

When it comes to the attractive geographical location of Serbia, it is implied that Serbia is the crossroads for three important transit corridors in the South Eastern Europe: the Danube Corridor (connects Germany and Austria with Turkey, The Black Sea and The Middle East), The Rhine-Main-Danube Canal is the single longest river traffic route in Europe, with Danube making a 588 kilometer passage through Serbia, and the third one, the corridor between Belgrade and Montenegrin port of Bar which connects the south of Italy with Romania, The Ukraine and Russia.

Apart from attractive geographical location, the size of the market is of paramount importance because Serbia covers around $40 \%$ of overall exYugoslav market. Having in mind that the capacity of industrial facilities in Serbia was meant for a large market, Serbia encountered a problem of where to export the surplus of its products, making it logical enough that once commercial blockages get eliminated Serbia will find space to put its surplus in proper places. The solution for Serbia's problem is establishing good regional cooperation in the economic field, but also specialization of economy with a view to transition to open commerce economy.

As everything else goes, the integration into the European Union has its pros and cons. Reasons for establishing strong regional partnerships include:

- the need to join the European Union through establishing good regional cooperation

- mutual awareness of the neighboring countries, respecting the limitations of the national markets, levels of economic power, the need for developing infrastructure, the need to regulate the increasing number of social and economic problems on regional and international level

- the external pressure of the European Union on the countries in the Balkans in order to establish a strong and effective cooperation

- the ability to fight against the pressure of the competition in the European Union market.

The economical reforms are advancing very slowly. It is a general impression that the private sector is still very weak, especially because it has not been systematically legislated. Domestic and foreign deficits are still very severe, and there are also serious structural obstacles in order for them to increase. In addition, the functioning of market mechanisms is burdened by numerous strains and legal insecurities.

The supply and demand tension for qualified labor force is one of the existing problems of the Serbian economy. The educational system produces a labor force which is not in accordance with the needs of the economy. 
Consequently, a high unemployment rate occurs within low and mid educated population, and in the long term within young highly educated people. In October 2012, Serbian Government ratified an educational strategy, which should bring about a number of effective measures and improve the quality of education by 2020 . But, the proposal of the action plan which should follow the administration of the strategy has not yet been compiled, and the fiscal consolidation has not followed the bills of the labor force market. Therefore, the educational strategy as a part of the economic reforms, remains and ambition that is to be proven and implemented. By looking at different sectors, the disadvantage of the current situation is surely the fact that the employment is greatly jeopardized, and that this trend is set to continue. For example, economy is being dominated by servicing sector, although there is a noticeable part of agriculture as well.

Improvement of the physical infrastructure is a constant need of a domestic economy. (Featherstone, Radelli, 2003, p. 146). The Government increased the scope of investments to $3.7 \%$ of the gross domestic product in 2012 but it remained low and recorded a decrease by $37 \%$ in the first eight months of 2013. The state administration faces problems that are well known and present for far too long. The Government of Serbia cannot claim ignorance, so it is required that it shows ability and will to fight for foreign direct investments.

The presence and importance of the Government cannot be stressed enough, especially when it comes to limiting helping companies. 2012 must not happen again when the Government helped the companies $7 \%$ more than the previous year and partook in the gross domestic product with 2,6\%. Looking at the statistical data, it can be said that the Government unevenly distributed its help between sectors. A separate problem concerns monopolistic structures, which are directed towards specific sectoral services and which in turn received more than the half of the overall help of the Government that was distributed between domestic companies. Standard international criteria implies that the help of the Government must be constantly checked in place, without any exceptions being made when it comes to private companies (Peters, Wright, 2001, p. 506). New measures of the Government assistance must be systematically notified before coming into force. The committee for the control of the Government assistance, as an independent entity, must insist on enforcing the regulations for compensation, that is, the return of the illegally given governmental assistance.

\section{Conclusion}

Serbia, therefore, accentuated the impulse of the reforms and intensified its contact with the neighboring countries, in order to establish positive contribution to the regional cooperation. The negotiations framework was adopted in the Council of the European Union, which signals the complete 
readiness of the European Union to support every step that has been undertaken by Serbia. In terms of economic criteria which need to be met, Serbia made a significant progress towards creating functional market economy. Serbia needs to make a noticeable endeavor in restructuring its economy, so that it can be soon ready to fight the pressure of the competition on the market of the European Union.

In 2012, Serbia went through another recession. However, the increase in export mitigated the effects of the weakened domestic demands and brought about a mild and uneven recovery in the first half of 2013. A number of endeavors were made in order to reach fiscal consolidations, especially in terms of revenue. A desire was shown to restructure government-owned corporations. In "Strategy of expansion and major challenges 2013-2014", which represents a specific form of communication between The European Committee and The European Parliament, it is said that Serbia made progress in war against corruption, as well as improvements in terms of proprietary rights (Communication from the Commission to the European Parliament and the Council, COM 2013, 700 final).

The growth remains limited none the less and the first signs of economic recovery in 2013 have not reflected on the labor force market. Unemployment and budget deficit are still very high. Strict demands of the labor market and constant employment rates are important if not the most important challenge right now. A managable ratified fiscal bill is still lacking. The presence of the Government in economic relations is important and government-owned corporations continue to accumulate great losses. This is the state Serbia finds itself at the moment as it is about to enter negotiations towards joining the European Union. Therefore, Serbia must continue with improving business environment and make strong endeavors in order to establish a competitive private sector. The functioning of market mechanisms is burdened by legal insecurities and corruption, too. Therefore, this segment represents an important and serious challenge.

If there is a question of whether Serbia has the possibilities to take on the responsibilities coming from the European Union or not, the answer is clear that it has to, above all, continue with adapting its legislative system to the demands of the European Union. The pivotal obligation is the ratification of acquis, starting with the ratification of appropriate legal acts and ending with its actual implementation. What is considered essential (and should therefore repeated) is the prevention of corruption, so in this sense there is a very important role of the legislative solutions on procurement, indepence of central bank, and especially, creating the institutional framework of politics for small and medium companies. However, the work is much more complex, as it transfers to other areas as well, such as the rights of intelectual property, the policy of agriculture development, environmental protection, human rights. 


\section{References}

European Commission (2013) „Communnication from the Commission to the European Parliament and the Council 'Enlargement Startegy and Main Challenges 20132014'“, COM 2013, 700 final, Brisel

European Commission (2013) „Presentation on the new approach on the chapter 23 and 24 in the accession negotitations", Brisel

Featherstone, K., Radelli, M.C. (2003) The Politics of Europeanization, Oxford: Oxford University Press Inc. New York

Marković, I. (2009) Evropska unija za i protiv, Niš: Ekonomski fakultet

OECD (2001) „Improving Policy Instruments through Impact Assessment“, Sigma Papers, No.31

OECD (2001) „The Management of EU Affairs in Candidate member States: Inventory of the Current State of Affairs“, Sigma Papers, No.23

OECD, (2007) „Enlargement of the European Union: an Analysis of the negotitations for Countries of the Wester Balkans“, Sigma Papers, No.37

Panke, D. (2010) „Good Instructions in No Time? Domestic Coordination of EU Policies in 19 Small States“, West European Politics, 33 (4): 770-790

Peters, B.G. Wright, V. (2001) The National Co-ordination of Euroepan Policy-Making, London: Routledge, European Union: Power and Policy-Making.

Schimmelfenning, F. and Sedelmeier, U. (2004) „Governance by conditionality: EU rule transfer to the candidate countries of Central and Eastern Europe“, Journal of European Public Policy, 11 (4): 661-679

\section{SARADNJA REPUBLIKE SRBIJE I EVROPSKE UNIJE U PERIODU OTVARANJA PREGOVORA O PRISTUPANJU}

Apstrakt: Postupak pregovaranja između Srbije i Evropske unije otpočeo je na osnovu člana 49. Ugovora o EU. Postupak i razvoj pregovora biće vođeni progresom Srbije u pripremi pristupanja, posebno unutar okvira ekonomske i socijalne konvergencije. Napredak ce biti meren posebno $u$ ispunjavanju Kopenhaških kriterijuma, kao i uslova definisanih Sporazumom o stabilizaciji i pridruživanju. Takođe, pristupanje imlicira prihvatanje institucionalnog okvira Unije, poznatog kao acquis. Tekovine Evropske unije poseban značaj za Srbiju kao zemlju kandidata imaju u pogledu ekonomskih pitanja i njene jurisdikcije. U tom pravcu je od važnosti pregled podataka prikazanih u radu, koji se odnose na određene ekonomske kategorije, pre svih kretanje bruto društvenog proizvoda i stope (ne)zaposlenosti, kao i koraka koje je Srbija preduzimala na svom putu ka Uniji.

Ključne reči: pristupanje, BDP, zaposlenost, harmonizacija, konkurentnost 